\title{
Knowledge, Attitude, and Practices towards the COVID-19 Pandemic among Undergraduate Students
}

\author{
Joy David Marcellino Triditra Limbong, ${ }^{1}$ Kuswinarti, ${ }^{2}$ Truly Sitorus ${ }^{2}$ \\ ${ }^{1}$ Faculty of Medicine Universitas Padajadjaran, Indonesia, ${ }^{2}$ Department of Biomedical Sciences \\ Faculty of Medicine Universitas Padjadjaran, Indonesia
}

\section{Abstract}

Background: Coronavirus disease-2019 (COVID-19) has caused serious implications and has received a lot of international attention, especially in public health sector. The main strategy for containing the COVID-19 pandemic includes preventive methods such as wearing masks, which requires individual awareness and initiative to adhere to the protocol. This study described the level of knowledge, attitude, and practices towards the COVID-19 pandemic among undergraduate students who were selected due to their high mobility and rate of activity.

Methods: This study used a descriptive design and a cross-sectional approach, conducted from October to November 2020. Undergraduate students from all faculties of Universitas Padjadjaran Year 20172019 were invited to participate, using an online questionnaire to assess the knowledge, attitude, and practices towards the COVID 19 pandemic. The result was given numeric values and scored. The mean value of the scores was used as a reference value to describe the level of knowledge, attitude, and practices.

Results: From a total of 483 students, $99.5 \%$ had good knowledge, $87.9 \%$ had good attitude, and $67 \%$ had a good practices towards COVID-19.

Conclusions: The overall levels of knowledge, attitudes, and practices towards COVID-19 among undergraduate students are good, as well as the adherence to government health protocols and initiatives in seeking information regarding COVID-19. Several specific areas such as transmission through dead bodies, exercise and vitamin supplementation, and anxiety when reading information about COVID-19 are areas of interest for the improvement of education.

Keywords: Attitude, coronavirus disease-2019, knowledge, practices, students

\section{Introduction}

Coronavirus disease-2019 (COVID-19), a disease caused by Severe Acute Respiratory Syndrome Coronavirus-2 (SARS-CoV-2) has caused serious implications and received a lot of international attention, especially in public health sector. ${ }^{1}$ The pandemic has affected 191 countries in the world, and Indonesia is one of the countries affected. The first case of COVID-19 was detected in Wuhan, China in late December 2019. ${ }^{1}$ As of December 2020, 543,975 confirmed cases and 17,081 deaths caused by COVID-19 have been reported in Indonesia. ${ }^{2}$ This constant rise in the confirmed case and death numbers due to COVID-19 are affected by several factors such as central and regional government health protocols, population density, individual adherence towards government health protocols, and quality of the national health care system. ${ }^{3}$

Several medications have been used as pharmacological therapy for COVID-19, such as glucocorticoids, Janus Kinase (JAK) inhibitors which have been proven to improve clinical outcomes and azithromycin which has been proven to have antiviral activity towards SARSCoV-2, along with several other medications. ${ }^{4}$ Although potential therapies for COVID-19 exist, there is still no specific pharmacological therapy for COVID-19. ${ }^{5}$ The current best strategy in containing the COVID-19 pandemic

Correspondence: Joy David MarcellinoTriditra Limbong, Faculty of Medicine Universitas Padjadjaran, Jalan Raya Bandung Sumedang KM 21, Jatinangor, Sumedang Indonesia, E-mail: joy17001@mail.unpad.ac.id 
are preventive methods such as wearing masks, frequent hand washing, and physical distancing.6,7 These preventive methods require individual awareness and initiative to adhere to these protocols. ${ }^{8}$ Knowledge, attitude, and practices towards disease is an essential factor in determining health decisions and health outcomes. ${ }^{9}$

Young adult is an important group to study since this age group has been reported to have lower adherence to government health protocols. This age group also commonly presents with mild symptoms or asymptomatic. Since they have high social activity and mobility, this age group greatly contributes to the rise of the COVID-19 confirmed cases and mortalities. ${ }^{10}$

This study aimed to describe the level of knowledge, attitude, and practices of Universitas Padjadjaran undergraduate students towards the COVID-19 pandemic. Furthermore, the level of adherence of the students towards the government protocols, as a part of the young adult age group was described.

\section{Methods}

This study used a descriptive design and a cross-sectional approach. It was carried out from October to November 2020. The inclusion criteria were undergraduate students from 16
Faculties of Universitas Padjadjaran from the year of 2017-2019 who had voluntarily agreed to participate by filling out an informed consent form. The exclusion criteria were students who incorrectly filled out the questionnaire. The sampling method used was total sampling, and a total of 483 students had participated in this study. This study had been approved by the Research Ethics Committee, Universitas Padjadjaran no. 1012/UN6.KEP/EC/2020.

The data was collected using an online questionnaire created with Google Forms. The questionnaire was acquired from a previous study with several edits, with approval from the author. ${ }^{11}$ The questionnaire consisted of 32 questions, comprised of 14 knowledge questions, 6 attitude questions, and 12 practice questions. The questionnaire also acquired characteristics of the subjects such as faculty and year.

The knowledge question answer choices were "true" or "false", with a maximum score of 14. The answers of the respondents for the knowledge questions were decided to be correct or incorrect by cross-checking the answers with information from the latest literature on COVID-19. The attitude question answer choices were "strongly agree", "agree", "neutral", "disagree", or "strongly disagree", with a maximum score of 30 . The practices questions answer choices were "always", "often", "sometimes", "rarely", or "never", with

Table 1 Characteristics of Undergraduate Students of Universitas Padjadjaran

\begin{tabular}{lcc}
\hline \multicolumn{1}{c}{ Variables } & $\begin{array}{c}\text { Frequency } \\
(\mathbf{n = 4 8 3})\end{array}$ & $\begin{array}{c}\text { Percentage } \\
\text { (\%) }\end{array}$ \\
\hline Year & & \\
2017 & 239 & 49.5 \\
2018 & 139 & 28.8 \\
2019 & 105 & 21.7 \\
Faculty & & \\
Agriculture Industrial Technology & 3 & 0.6 \\
Agriculture & 25 & 5.2 \\
Animal Husbandry & 9 & 1.9 \\
Communication Science & 20 & 4.1 \\
Cultural Sciences & 16 & 3.3 \\
Dentistry & 19 & 3.9 \\
Economics and Business & 13 & 2.7 \\
Fishery and Marine Science & 2 & 0.4 \\
Geological Engineering & 0 & 0 \\
Law & 10 & 2.1 \\
Mathematics and Natural Science & 20 & 4.1 \\
Medicine & 285 & 59 \\
Nursing & 24 & 5 \\
Pharmacy & 8 & 1.7 \\
Psychology & 8 & 1.7 \\
Social and Political Science & 21 & 4.3 \\
\hline
\end{tabular}


Table 2 Knowledge, Attitude, and Practices towards the COVID-19 Pandemic among Undergraduate Students of Universitas Padjadjaran

\begin{tabular}{|c|c|c|}
\hline Variables & $\begin{array}{c}\text { Frequency } \\
(n=483)\end{array}$ & $\begin{array}{c}\text { Percentage } \\
(\%)\end{array}$ \\
\hline $\begin{array}{l}\text { Knowledge } \\
\text { Good } \\
\text { Satisfactory }\end{array}$ & $\begin{array}{c}481 \\
2\end{array}$ & $\begin{array}{c}99.5 \\
0.5\end{array}$ \\
\hline $\begin{array}{l}\text { Attitude } \\
\text { Positive } \\
\text { Negative }\end{array}$ & $\begin{array}{c}425 \\
58\end{array}$ & $\begin{array}{c}87.9 \\
42\end{array}$ \\
\hline $\begin{array}{l}\text { Practices } \\
\text { Positive } \\
\text { Negative }\end{array}$ & $\begin{array}{l}324 \\
159\end{array}$ & $\begin{array}{l}67 \\
33 \\
\end{array}$ \\
\hline
\end{tabular}

a maximum score of 60. Each answer was assigned a score, and each subject's total score was calculated. The average score for knowledge, attitude, and practices was used as a reference value. For knowledge, subjects with a score more than $75 \%$ of the maximum score were categorized as "good", and subjects with a score between $55 \%$ and $75 \%$ of the maximum score were categorized as "satisfactory", and subjects with a score less than $55 \%$ of the maximum score were categorized as "poor". For attitude and practices, subjects with a score of more than $75 \%$ of the maximum score were classified as "positive", and subjects with a score less than $75 \%$ of the maximum score were classified as "negative".

The questionnaire had been tested for validity with the Pearson Product formula and was considered valid with a correlation value of $\geq 0.5$. All knowledge and attitude questions achieved good validity. The reliability was tested with Cronbach's Alpha formula and considered reliable with a coefficient $\geq 0.7$. All knowledge and attitude questionnaires achieved good reliability. The validity and reliability testing was performed in September 2020 on 30 respondents. The respondents were randomly selected from several instant messaging groups consisting of Universitas Padjadjaran undergraduate students.

\section{Results}

In total, 483 undergraduate students had participated in this study, and all 483 students fulfilled the criteria previously set. The total amount of Universitas Padjadjaran students from the year 2017-2019 was 21,976 students, thus, only $2.2 \%$ of all students participated in this study. Most of the students who participated were from the year 2017 $(49.5 \%)$. The response rate from each faculty ranged from 0 to 285 responses, with the lowest response rate $(0 \%)$ from the Faculty of Geological Engineering, and the highest response rate $(59 \%)$ from the Faculty of Medicine (Table 1).

The majority of students had a "good" score on knowledge questions (99.5\%) as well as a good attitude (87.9\%) towards the COVID-19 pandemic. More than half of the respondents (67\%) had good practices for government COVID-19 protocols as shown in Table 2 .

The data for the knowledge questions were not normally distributed. The median of the scores acquired was 13 (range 10-14). More than $95 \%$ of respondents answered correctly on questions regarding etiology, symptoms, and treatment of COVID-19. Fewer respondents answered correctly on questions regarding transmission and spread, with only $89 \%$ answering correctly regarding transmission through dead bodies, and $81.4 \%$ answering correctly regarding spread through fomites.

The data for the attitude questions were not normally distributed. The median of the scores acquired was 25 (range 18-30). Most of the students recognized the importance of obeying government COVID-19 protocols, obtaining information about COVID-19, and had a positive view towards COVID-19 patients (Table 4).

The data for the practice questions were not normally distributed. The median of the scores acquired was 48 (30-60). Practices regarding protection from the transmission, received good scores, which were always wearing a mask when going outside (92.5\%), always washing their hands frequently (59.8\%), and often washing their hands frequently (31.1\%). Practices regarding a healthy lifestyle received poorer scores, with only $9.9 \%$ of students always routinely exercising and $15.7 \%$ often 
Table 3 Knowledge of Undergraduate Students of Universitas Padjadjaran towards COVID-19

\begin{tabular}{|c|c|c|c|}
\hline & Questions & $\begin{array}{l}\text { Correct } \\
(\%)\end{array}$ & $\begin{array}{l}\text { Incorrect } \\
(\%)\end{array}$ \\
\hline 1. & COVID-19 is a disease caused by SARS-CoV-2 & 95 & 5 \\
\hline 2. & $\begin{array}{l}\text { The main clinical symptoms of COVID-19 are fever, fatigue, dry cough, } \\
\text { and myalgia }\end{array}$ & 91.1 & 8.9 \\
\hline 3. & $\begin{array}{l}\text { People with COVID-19 also show no symptoms, called OTG (People } \\
\text { without Symptoms) }\end{array}$ & 99.8 & 0.2 \\
\hline 4. & $\begin{array}{l}\text { People with COVID-19 who have chronic diseases such as diabetes, } \\
\text { heart disease, and obesity have an increasingly severe condition }\end{array}$ & 95 & 5 \\
\hline 5. & $\begin{array}{l}\text { Children and teenagers do not need to make efforts to prevent COVID-19 } \\
\text { infection because they have a strong immune system }\end{array}$ & 98.8 & 1.2 \\
\hline 6. & $\begin{array}{l}\text { People with COVID-19 who show no symptoms or OTG (People without } \\
\text { symptoms) cannot infect the virus to others }\end{array}$ & 98.3 & 1.7 \\
\hline 7. & $\begin{array}{l}\text { COVID-19 is spread through the respiratory droplets of people infected } \\
\text { with COVID-19 }\end{array}$ & 92.5 & 7.5 \\
\hline 8. & $\begin{array}{l}\text { The dead bodies of people with COVID-19 who have not been buried can } \\
\text { be a source of the spread of the COVID-19 virus }\end{array}$ & 89 & 11 \\
\hline 9. & $\begin{array}{l}\text { COVID-19 only spreads through fomites, it does not spread through the } \\
\text { air }\end{array}$ & 81.4 & 18.6 \\
\hline 10. & $\begin{array}{l}\text { Currently, there is no effective drug for COVID-19, but the treatment of } \\
\text { early symptoms and intensive care can help people with COVID-19 to } \\
\text { recover }\end{array}$ & 99 & 1 \\
\hline 11. & $\begin{array}{l}\text { To prevent COVID-19 infection, we must avoid going to crowded } \\
\text { places like markets and train stations as well as avoid using public } \\
\text { transportation }\end{array}$ & 98.3 & 1.7 \\
\hline 12. & Avoiding travel across cities can prevent the spread of COVID-19 & 98.8 & 1.2 \\
\hline 13. & $\begin{array}{l}\text { The transmission of SARS-CoV-2 can be prevented by not touching the } \\
\text { face }\end{array}$ & 96.5 & 3.5 \\
\hline 14. & $\begin{array}{l}\text { Isolation and treatment of people infected with the COVID-19 virus are } \\
\text { effective ways to reduce the spread of the virus }\end{array}$ & 99.2 & 0.8 \\
\hline
\end{tabular}

routinely exercising, while only $17.6 \%$ always received enough rest, and $30 \%$ often received enough sleep.

\section{Discussion}

This study aimed to describe the knowledge, attitude, and practices of Universitas Padjadjaran undergraduate students towards the COVID-19 pandemic, resulting in most of the students have good knowledge (99.5\%), positive attitude $(87.9 \%)$, positive practices (67\%). A similar study has been previously conducted in another part of Indonesia, although with lower percentage. ${ }^{11}$ However, our study has a higher percentage result compared to other studies in Bangladesh and India. ${ }^{12,13}$

Regarding knowledge, correct answer was given on etiology (95\%), clinical symptoms (91.1\%), and management of COVID-19 (99\%), with a lower percentage on questions regarding transmission and spread of COVID-19, specifically spread through dead bodies of COVID-19 patients, correlates with previously cited studies from Indonesia and India. ${ }^{11,13}$ The large proportion of respondents answering correctly on questions regarding etiology, clinical symptoms, and management of COVID-19 indicates that information provided by the government through the official website covid19.go.id as well as television and radio has provided good education, however, some topics need further education.

Answer that dead bodies of COVID-19 patients are still able of spreading COVID-19 was given from $11 \%$ of thestudents. This answer is incorrect since the Indonesian Ministry of 
Table 4 Attitude of Undergraduate Students of Universitas Padjadjaran towards the COVID-19 Pandemic

\begin{tabular}{|c|c|c|c|c|c|}
\hline Questions & $\begin{array}{l}\text { Strongly } \\
\text { Agree } \\
(\%)\end{array}$ & $\begin{array}{c}\text { Agree } \\
\text { (\%) }\end{array}$ & $\begin{array}{c}\text { Neutral } \\
(\%)\end{array}$ & $\begin{array}{c}\text { Disagree } \\
(\%)\end{array}$ & $\begin{array}{l}\text { Strongly } \\
\text { Disagree } \\
(\%)\end{array}$ \\
\hline $\begin{array}{l}\text { 1. Keeping up with the information regarding } \\
\text { the number of COVID-19 cases is important } \\
\text { for the community }\end{array}$ & 52.6 & 37.3 & 9.3 & 0.8 & 0 \\
\hline $\begin{array}{l}\text { 2. After knowing the information on the } \\
\text { number of cases of COVID-19, I felt worried/ } \\
\text { scared }\end{array}$ & 14.7 & 48.7 & 27.5 & 7.2 & 1.9 \\
\hline $\begin{array}{l}\text { 3. Keeping up with the information regarding } \\
\text { the government's call for COVID-19 } \\
\text { preventive efforts is important for the } \\
\text { community }\end{array}$ & 79.9 & 17.8 & 1.9 & 0 & 0.4 \\
\hline $\begin{array}{l}\text { 4. All people with COVID-19 are those who } \\
\text { violate the government's call in the efforts to } \\
\text { prevent transmission of COVID-19 }\end{array}$ & 2.5 & 4.8 & 21.1 & 49.1 & 22.6 \\
\hline $\begin{array}{l}\text { 5. People with COVID-19 should not be given a } \\
\text { negative stigma in society }\end{array}$ & 67.5 & 25.1 & 6.4 & 1 & 0 \\
\hline $\begin{array}{l}\text { 6. Peoplewith COVID-19whoisolatethemselves } \\
\text { show that they have a responsibility in } \\
\text { preventing the transmission of COVID-19 }\end{array}$ & 81.8 & 16.6 & 1.7 & 0 & 0 \\
\hline
\end{tabular}

Health has issued specific protocols for the burial of COVID-19 patients which ensures the safety of everyone involved. Knowledge about the spread through dead bodies is important in Indonesia due to recent occurrences of rejection of COVID-19 patients' dead bodies in some parts of Indonesia. This phenomenon of dead bodies and burial rejection may cause substantial negative mental and social effects on the patient's families. ${ }^{14}$ COVID-19 is only able to spread through fomites, and not able of spreading through air according to $18.6 \%$ of students. This answer does not correlate with a study that demonstrated COVID-19 that spread through respiratory droplets of persons with COVID-19, as well as through contact with fomites. ${ }^{1}$ Knowledge regarding COVID-19 transmission is important because the transmission is the basis of preventive methods such as wearing masks, washing hands frequently with soap, and physical distancing. Therefore, a correct understanding of the transmission of COVID-19 may improve adherence to government health protocols. Good knowledge of COVID-19 has also been proven to correlate with better health protocol practices. $^{11}$

On attitude, most students have good adherence to government protocols and recognized the threat and importance of dealing with COVID-19. Interestingly, reading the information regarding COVID-19 has caused them to experience anxiety and fear. This result is supported by a previous study in Bangladesh ${ }^{15}$ in which students admitted to experiencing mild to severe depression, and mild to severe anxiety. This may be an area of further focus for education by the government, on methods to control and reduce anxiety and stress in the middle of the COVID-19 pandemic.

It is important to acquire information regarding COVID-19 from the government and to adhere to government health protocols. This study also shows that a large majority of the students have good individual awareness and adherence towards information and protocols regarding COVID-19 from the government. Not all COVID-19 patients are violators of government health protocols. One example is the existence of family or house clusters of COVID-19 transmission. In family or house clusters, an individual who has adhered to government health protocols may contract COVID-19 from other family or house members who have been exposed to COVID-19 when going outside. ${ }^{16}$ However, a negative stigma should not be given to COVID-19 patients. Negative stigma towards patients of a particular disease has been shown to cause substantial mental and social impacts that may outgrow the primary disease, especially in pandemic situations such as the COVID-19 pandemic. $^{17}$

On questions about practices, the students 
Table 5 Practices regarding COVID-19 among Undergraduate Students of Universitas Padjadjaran

\begin{tabular}{|c|c|c|c|c|c|c|}
\hline & Questions & $\begin{array}{l}\text { Strongly } \\
\text { Agree } \\
(\%)\end{array}$ & $\begin{array}{c}\text { Agree } \\
(\%)\end{array}$ & $\begin{array}{c}\text { Neutral } \\
(\%)\end{array}$ & $\begin{array}{l}\text { Disagree } \\
(\%)\end{array}$ & $\begin{array}{l}\text { Strongly } \\
\text { Disagree } \\
(\%)\end{array}$ \\
\hline 1. & $\begin{array}{l}\text { In the last few days, have you worn a mask } \\
\text { when you were in a crowded place? }\end{array}$ & 92.5 & 6.4 & 0.4 & 0 & 0.6 \\
\hline 2. & $\begin{array}{l}\text { In the last few days, have you implemented } \\
\text { physical distancing when you were in the } \\
\text { crowd? }\end{array}$ & 51.3 & 36.2 & 11.2 & 1 & 0 \\
\hline 3. & $\begin{array}{l}\text { In the last few days, have you used hand } \\
\text { sanitizer when you were in crowded } \\
\text { places? }\end{array}$ & 65 & 23.4 & 10.4 & 1 & 0 \\
\hline 4. & $\begin{array}{l}\text { In the last few days, have you washed your } \\
\text { hands with soap after going to a crowded } \\
\text { place? }\end{array}$ & 72.5 & 17.6 & 8.7 & 1.2 & 0 \\
\hline 5. & $\begin{array}{l}\text { In the last few days, have you immediately } \\
\text { changed your clothes before entering the } \\
\text { house and having contact with family } \\
\text { members? }\end{array}$ & 38.9 & 31.7 & 19.9 & 6.8 & 2.7 \\
\hline 6. & $\begin{array}{l}\text { As a college student, have you educated } \\
\text { people around you with the knowledge of } \\
\text { the preventive efforts of COVID-19? }\end{array}$ & 19.5 & 44.9 & 29.4 & 5.4 & 0.8 \\
\hline 7. & $\begin{array}{l}\text { In the last few days, I have eaten vegetables } \\
\text { and fruit. }\end{array}$ & 9.9 & 15.7 & 32.9 & 30.2 & 11.2 \\
\hline 8. & $\begin{array}{l}\text { In the last few days, I have had enough } \\
\text { rest. }\end{array}$ & 12 & 20.1 & 30.2 & 23.2 & 14.5 \\
\hline 9. & $\begin{array}{l}\text { In the last few days, I have been exercising } \\
\text { routinely. }\end{array}$ & 19 & 33.5 & 32.7 & 13 & 1.7 \\
\hline 10. & $\begin{array}{l}\text { In the last few days, I have taken vitamins } \\
\text { or supplements to increase my immune } \\
\text { system. }\end{array}$ & 59.8 & 31.1 & 7.7 & 1.4 & 0 \\
\hline 11. & $\begin{array}{l}\text { In the last few days, I have been cleaning } \\
\text { up my house more frequently. }\end{array}$ & 19 & 33.5 & 32.7 & 13 & 1.7 \\
\hline & $\begin{array}{l}\text { In the last few days, I have been washing } \\
\text { my hand with soap more. }\end{array}$ & 59.8 & 31.1 & 7.7 & 1.4 & 0 \\
\hline
\end{tabular}

have shown good practices on the use of masks, physical distancing, and frequent hand washing. Interestingly, some students still have routinely performed practices regarding a healthy lifestyles, such as regular exercise, vitamin consumption, and regular rest. This is of great significance due to the proven effect of exercise and vitamins towards improving immune status to prevent COVID-19.18,19 Furthermore, the majority wear masks as well as performing physical distancing when present in a crowded place. Moreover, most of the students wash their hands with soap. Taken together, the data reveals that adherence towards the main preventive methods of COVID-19 is good which is wearing masks, washing hands with soap, and physical distancing. Interestingly, a few students do not change their clothes before entering their house and contacting family members, and this requires further improvement as SARSCoV-2 can stay viable on clothes for up to 96 hours, and thus becoming a possible source of transmission towards family members. ${ }^{20}$

The limitations of the current study are among others that the distribution of the respondents throughout the faculty are uneven with the largest proportion is from the Faculty of Medicine. This might be a bias toward the study result.

In conclusion, the undergraduate student in Universitas Padjadjaran has a good level of overall knowledge, attitude, and practices towards COVID-19. Further improvement 
needs to be implemented in promoting the government website as the main hub of information and simplifying information regarding COVID-19 transmission and spread. Education about lifestyle practices such as exercise, rest, and a healthy diet must be reinforced, just as important as wearing masks and frequent handwashing.

\section{References}

1. Rothan HA, Byrareddy SN. The epidemiology and pathogenesis of coronavirus disease (COVID-19) outbreak. J Autoimmun. 2020;109:102433.

2. John Hopkins University \& Medicine. COVID-19 dashboard by the Center for Systems Science and Engineering (CSSE) at Johns Hopkins: global map. 2020. [cited 20/12/20] Available from: https:// coronavirus.jhu.edu/map.html.

3. PriyadarsiniSL, Suresh M. Factors influencing the epidemiological characteristics of pandemic COVID 19: A TISM approach. International Journal of Healthcare Management. 2020;13(2):89-98.

4. Rabby MII. Current drugs with potential for treatment of COVID-19: a literature review. J Pharm Pharm Sci. 2020;23(1):58-64.

5. Cortegiani A, Ingoglia $G$, Ippolito $M$, Giarratano A, Einav S. A systematic review on the efficacy and safety of chloroquine for the treatment of COVID-19. J Crit Care. 2020;57:279-83.

6. Adhikari SP, Meng S, Wu Y-J, Mao Y-P, Ye R-X, Wang Q-Z et al. Epidemiology, causes, clinical manifestation and diagnosis, prevention and control of coronavirus disease (COVID-19) during the early outbreak period: a scoping review. Infect Dis Poverty. 2020;9:29.

7. Lewnard JA, Lo NC. Scientific and ethical basis for social-distancing interventions against COVID-19. Lancet Infect Dis. 2020; 20(6):631-3.

8. Gadarian SK, Goodman SW, Pepinsky TB. Partisanship, health behavior, and policy attitudes in the early stages of the COVID-19 pandemic. SSRN e-Journal. 2020. [cited 20/12/12] Availabe from: https://dx.doi. org/10.2139/ssrn.3562796.

9. Szymona-Pałkowska K, Janowski K, Pedrycz A, Mucha D, Ambroży T, Siermontowski P,et al. Knowledge of the disease, perceived social support, and cognitive appraisals in women with urinary incontinence. Biomed Res Int. 2016;2016:3694792.

10. Nivette A, Ribeaud D, Murray A, Steinhoff
A, Bechtiger L, Hepp U, et al. Noncompliance with COVID-19-related public health measures among young adults in Switzerland: Insights from a longitudinal cohort study. Soc Sci Med. 2021;268:113370.

11. Saefi M, Fauzi A, Kristiana E, Adi WC, Muchson M, Setiawan ME,et al. Validating of knowledge, attitudes, and practices questionnaire for prevention of COVID-19 infections among undergraduate students: A RASCH and factor analysis. EURASIA J Math Sci Tech Ed. 2020;16(2):em1926.

12. Ferdous MZ, Islam MdS, Sikder MdT, Mosaddek ASMd, Zegarra-Valdivia JA, Gozal D. Knowledge, attitude, and practice regarding COVID-19 outbreakin Bangladesh: An online-based cross-sectional study. PLoS One 2020;15(10):e0239254.

13. Singh JP, Sewda A, Shiv DG. Assessing the knowledge, attitude and practices of students regarding the COVID-19 pandemic. Journal of Health Management. 2020;22(2): 281-90.

14. Casman C, Kurniawan K, Wijoyo EB, Pradana AA. Studi literatur: penolakan jenazah COVID-19 di Indonesia. Jurnal Kesehatan Manarang. 2020;6(Khusus):18-26.

15. Islam MdA, Barna SD, Raihan $H$, Khan MdNA, Hossain MdT. Depression and anxiety among university students during the COVID-19 pandemic in Bangladesh: A web-based cross-sectional survey. PLoS One. 2020;15(8):e0238162.

16. Wang Z, Ma W, Zheng X, Wu G, Zhang R. Household transmission of SARS-CoV-2. Journal of Infection.2020; 81(1): 179-182.

17. Sulistiadi W, Slamet SR, Harmani N. Handling of Public Stigma on COVID-19 in Indonesian Society. Kesmas: National Public Health Journal. 2020; Special Issue(1):70-6.

18. Xu Z, Chen Y, Yu D, Mao D, Wang T, Feng D,et al. The effects of exercise on COVID-19 therapeutics: A protocol for systematic review and meta-analysis. Medicine (Baltimore).2020; 99(38): e22345.

19. Bilezikian JP, Bikle D, Hewison M, Lazaretti-Castro M, Formenti AM, Gupta A et al. Mechanisms in endocrinology: Vitamin D and COVID-19. Eur J Endocrinol. 2020;183(5): R133-47.

20. Harbourt DE, Haddow AD, Piper AE, Bloomfield H, Kearney BJ, Fetterer D et al. Modeling the stability of severe acute respiratory syndrome coronavirus 2 (SARSCoV-2) on skin, currency, and clothing. PLoS Negl Trop Dis.2020;14(11): e0008831. 